${ }^{1}$ Assoc. Prof. Dr., Kırıkkale University, Keskin Vocational High School, Marketing, Kırıkkale, Turkiye, iborganizer@gmail.com

ORCID: 0000-0002-9584-6126

Submitted: $21 / 01 / 2021$

Revised: $10 / 03 / 2021$

Accepted: 17/03/2021

Online Published: 25/04/2021

Citation: Bozac1, İ., Effect of guilt and the love of money on avoiding luxury clothing brand purchasing, tujom (2021) 6 (1):21-31, doi:

https://doi.org/10.30685/tujom.v6i1.106

\section{Effect of guilt and the love of money on avoiding luxury clothing brand purchasing}

\author{
Suçluluk duygusu ve para aşkının, lüks giyim markası satın almaktan \\ kaçınmaya etkisi
}

\author{
İbrahim Bozac1 ${ }^{1}$
}

\begin{abstract}
Consumers may avoid purchasing luxury brands, which may cause negative feelings, such as low income and moral beliefs. It is essential to know the factors that affect the intentions to avoid luxury consumption and develop suggestions for businesses that market these products and know this relatively less studied aspect of consumer behaviour. In this study, the feeling of guilt arising from purchasing high-priced luxury clothing products and the effect of love of money, which expresses the individual's approach to money, on avoiding purchasing these products is questioned. Within the scope of the research, primary data were collected by face-to-face questionnaire method in Kirikkale province of Turkey, and the obtained data were tested with the structural equation model. As a result of the analysis, the feeling of guilt and the love of money (except for the motivation and wealth dimension) affect avoidance of purchasing luxury clothing. It was concluded that the variable affecting this intention the most was guilt and that the success dimension of the love of money had a negative effect. Finally, the research results were interpreted, and recommendations were made to researchers and businesses.
\end{abstract}

Keywords: Guilt, the Love of Money, Luxury Product, Consumer, Purchase, Avoidance

Jel Codes: D120, D910, E210

Öz

Tüketiciler, düşük gelir ve ahlaki inançlar gibi nedenlerle olumsuz duygulara neden olabilecek lüks markaları satın almaktan kaçınabilmektedir. Lüks tüketimden kaçınma niyetlerini etkileyen faktörleri bilmek, bu ürünleri pazarlayan işletmeler için öneriler geliştirebilmek ve tüketim davranışının bu görece daha az çalışılmış yönünü bilmek için önemlidir. Bu çalışmada, yüksek fiyatlı lüks giyim ürünleri satın almaktan kaynaklanan suçluluk duygusu ve bireyin paraya yaklaşımını ifade eden para aşkının, bu ürünleri satın almaktan kaçınmaya etkisi sorgulanmaktadır. Araştırma kapsamında Türkiye'nin Kırıkkale ilinde birincil veriler yüz yüze anket yöntemi ile toplanmış ve elde edilen veriler yapısal eşitlik modeli ile test edilmiştir. Analiz sonucunda; suçluluk duygusu ve para aşkının (motivasyon ve zenginlik boyutu hariç) lüks giyimden kaçınmayı etkilediği belirlenmiştir. Bu niyeti en çok etkileyen değişkenin suçluluk duygusu olduğu ve para sevgisinin başarı boyutunun olumsuz etkisinin olduğu sonucuna varılmıştır. Son olarak, araştırma sonuçları yorumlanmış ve araştırmacı ve işletmelere önerilerde bulunulmuştur.

Anahtar Kelimeler: Suçluluk, Para aşkı, Lüks Ürün, Tüketici, Satın Alma, Kaçınma

Jel Kodlari: D120, D910, E210 


\section{Introduction}

Although luxury consumption causes consumer to gain utility, it can cause negative emotions that people avoid (Boujbel \& d'Astous, 2015; Hagtvedt \& Patrick, 2015), especially in cases where lowincome families should be thriftier in consumption decisions. Otherwise, conflicts arise (Hamilton, 2009). Moreover, low price is the primary factor in purchasing decisions of low-income consumers (Marcos, 2020), and it is seen that people avoid excessive or luxurious consumption when having difficulty meeting their basic needs (Riad, 2011; Lee-Wingate \& Corfman, 2010). Based on the idea that people can avoid purchasing high-priced luxury brands that can cause negative feelings because of mentioned several reasons, this study questions the effect of guilt and love of money on this intention.

In this context, despite its prevalence in human life, the attention shown in consumer studies to negative emotions such as guilt and their effects is limited (Bonsu \& Main, 2006). Besides, studies are showing that the love of money, which expresses positive attitudes towards money, is a factor affecting various consumer behaviours, especially for unethical behaviours (Vitell et al., 2006; Vitell et al., 2007; Tang, 2007; Tang \& Chen, 2008; Elias \& Farag, 2010; Lau et al., 2011; Tang \& Liu, 2012; Chen et al., 2014; Tang, 2016; Flurry \& Swimberghe, 2016). In this study, possible effects of guilt resulting from purchasing high priced luxury brands and the love of money on avoiding purchasing luxury brands are questioned.

\section{Anti-consumption and avoiding luxury brands}

Anti-consumption refers to consumer's preference to reject or diminish certain goods, services or brands. The phenomenon of opposition to consumption and its reasons emerges as an essential research topic in marketing science (Kozinets et al., 2010; Lee et al., 2011). From the environmental point of view, the idea that efficient and sustainable technologies are not sufficient for sustainable production/consumption and consumption should be reduced in general is accepted (Joanes, 2019). Although consumers relate high quality with high price; they can prefer renewable fabrics, quality products before the well-known brands, engage in recycling behaviours (McNeill \& Moore, 2015) and prefer second-hand products with economic motivations (getting more products for the same price, etc.) (Styvén \& Mariani, 2020). In addition to methods such as recycling activities and sustainable production, businesses can strategically approach reducing the number of products produced, used and disposed of, and invest in areas such as the production of durable clothing products, resale of used products and high-quality recycled products (Freudenreich \& Schaltegger, 2020).

As a type of consumption opposition, brand avoidance is expressed as avoiding purchasing or using brands with specific characteristics. This may arise from reasons such as; experiences in which expectations are not met, brand image not being compatible with the individual's identity or brand values or associations not being compatible with the individual's ideological beliefs (Lee et al., 2009; Gram et al., 2017). However, it is thought that there is need for more research on the reasons for avoiding certain brands. At this point, the emotion of guilt and the love of money can be essential factors.

\section{Guilt emotion and its reasons}

The guilt expressed among negative emotions is caused by violation of or being in a situation contrary to personal or social norms (McGraw, 1987; Daniel, 2000). Guilt, which is an undesired emotion caused by behaviour, non-behaviour, circumstances or intentions, can be more easily aroused than other emotions such as sadness. Three form of guilt can be expressed: expected guilt due to possible violation of standards, reactive guilt arising from the violation of standards, and existential guilt due to incompatibility between the well-being of the individual and others (Rawlings, 1970; Izard, 1977).

Similarly, the feeling of guilt in the consumer is caused by acting or not acting in accordance with the norms or standards. Buying an expensive bowling ball without thorough research or consultation, not using the earned money in socially beneficial works, not being able to start dieting or behaving in certain behaviours like not helping can cause guilt in the consumer (Dahl et al., 2003).

In the qualitative research of Burnett and Lunsford (1994), which was carried out based on the fact that the dimensions of the consumer feeling of guilt have not been investigated sufficiently; consumer guilt summarized under the headings of; financial, health, moral and social responsibility. Financial guilt occurs when a consumer makes impulsive purchases, does not bargain enough, buys unneeded products, or overspendings. Businesses tell customers that they are worthy of spending the money they 
earn on the products to convince them. Health guilt is about not paying enough attention to health. Buying fattening products or smoking can cause this. In this regard, food businesses explain that meals will be consumed without guilt and with total pleasure in advertisements. Moral belief guilt occurs when an individual violates his moral values. For example, it may not be suitable to smoke, drink alcohol and gamble out of faith, and consumers who choose them may experience guilt. Those who market pregnancy control products promote the notion that consumers should not experience guilt by respecting the lives of others. Social responsibility guilt emerges mainly in donations, environmental issues, family responsibilities and gift-receiving behaviours. Organizations that market these ideas also take advantage of this feeling by explaining that lives will be lost without the support of people or that a clean and safe world should be left to future generations (Burnett \& Lunsford, 1994). It can be stated that guilt can be resulted from purchasing luxury products and it is thought that those who do not want to experience this feeling can avoid this behavior.

Feeling of guilt by businesses can be used in the content of communications such as advertising to mobilize consumers (Lee-Wingate, 2006), as a type of negative attractiveness, in the direction of creating an emotional imbalance, discomfort and desire to eliminate it (Hibbert et al., 2007; Basil et al., 2006). According to this, meals are positioned as "full pleasure without guilt", and social problems are marketed with guilt appeal (Burnett \& Lunsford, 1994). For example, nondurable consumer goods businesses, healthcare and non-profit organizations commit the guilt of customers who compromise or do not use the product (special day reminder services, etc.) or compare the happiness of those who use the product unhappiness of those who do not use it. And it is seen that this emotion can be used widely in advertisements at a comparable level with other attractiveness such as humour, sexuality and comparison in donor organizations (Huhmann \& Brotherton, 1997). Another area where businesses use guilt is cause-related marketing as a public relations practice, and guilt attractiveness used in this field can be more effective than others (Chun-Tuan, 2011).

In short, the effects of guilt on consumers cause businesses to make efforts to reduce this feeling. In this respect, methods such as benefiting from guilt appeal in advertisements (Soscia et al., 2008), reducing the perceptions of indulging in consumer comfort, and enabling others to make favourable comparisons with their consumption can be effective (Lee-Wingate, \& Corfman, 2010). Consumers may also make choices such as preferring or not choosing a particular product/brand to avoid guilt emotion.

Studies show that guilt is a depressive feeling (Krugler \& Jones, 1992) and is formed by awareness of the violation of individual or social moral norms (Watson \& Spence, 2007). At this point, this emotion can be emerging from impulsive consumption (Hanks \& Mattila, 2014), compulsive consumption (Miao, 2011), hedonistic consumption (Xu \& Schwarz, 2009; Lin \& Xia, 2009) and can discourage these consumption behaviours (Lee-Wingate \& Corfmann, 2010). For example; it is possible for an individual to feel guilty in pleasurable consumptions like; eating a meal that he/she should not eat like dessert (Sukhdial \& Boush, 2004), going on an expensive vacation, choosing a luxury hotel, buying a piece of jewellery (Oliver, 1993), etc. These purchasing behaviours can lead to guilt due to the individual's perceptions about himself/herself as fastidious, unfair and unruly (Lee-Wingate, \& Corfman, 2010).

\section{The love of money}

Although the subject of love in psychology focuses more on interpersonal relationships, the idea that love can be directed to a particular object has been recently accepted since people can see certain objects (money etc.) as indispensable or irreplaceable and they make great sacrifices for them (Ahuvia, 1992). At this point, the love of money expressed as an individual's attitudes and desires towards money, causes money to be seen as a symbol of happiness (Tang, 2007; Tang \& Chen, 2008). Having rebellious attitudes towards money will inevitably affect consumption and saving behaviours/intentions since they are related to increasing or decreasing monetary resources.

It is seen that the relationship between the love of money and behaviour in general, and the love of money and consumption in particular, draws attention from an ethical point of view. Although money as a pure object is not bad, it is stated that the love of money is wrong because it affects unethical behaviours (overwork, exploitative behaviour, theft, bribery, etc.) (Tang \& Chen, 2008; Tang, 2007; Chen et al., 2014; Tang \& Liu, 2012; Elias \& Farag, 2010). Similarly, studies show that consumers' ethical behaviours (buying pirated products or keeping silent in the face of theft) are related to perceptions or attitudes towards money (Vitell et al., 2006; Vitell et al., 2007; Lau et al., 2011; Tang, 2016; Flurry \& 
Swimberghe, 2016). At this point, individuals with a love of money may be expected to set goals or norms to protect money and avoid expenditures perceived as unnecessary. In this respect, it is possible for those who love money to experience guilt because of buying high-priced luxury products.

\section{Hypothesis development}

Feeling of guilt can affect several consumer behaviours, intentions and attitudes like; avoiding products that violate social or cultural norms (Lascu, 1991; Cruz et al., 2013), benevolent behaviors like donations (Dahl \& Honea, 2005; Peloza et al., 2013), ethical and sustainable consumption behaviours (Steenhaut \& Can Kenhove, 2006; Arli et al., 2016; Theotokis \& Manganari, 2015), having positive attitudes towards green products (Onwezen et al., 2014) etc. To reduce guilt, people can prepare for purchasing, determine the practical value of purchasing and decide not to purchase etc. (Lee-Wingate \& Corfmann, 2010).

At this point, hedonistic goods and services (Okada, 2005; Chun et al., 2007) and because of the features perceived as unnecessary, consumers can avoid buying high-priced products (Nowlis \& Simonson, 1996). Although consumers get from luxury consumption some pleasure, they can reduce their fancy or luxury consumption to balance their guilt and prefer more sustainable and low-priced products (De Lenne \& Vandenbosch, 2017). Ki et al.'s (2017) research-based on "balance theory", which is claimed that human happiness is affected by negative emotions as well as positive emotions; demonstrated that guilt as a negative emotion affects the consumer's repeat purchasing behaviour of luxury products (Ki et al., 2017). Based on these explanations, the following research hypothesis is put forward for testing:

\section{"H1: Guilt affects avoiding purchasing high-priced luxury clothing products."}

In the science of economics, the idea that money generates measurable utility for consumers, the marginal utility of money decreases significantly depending on the consumption amount, and consumer can choose it over products have been accepted and discussed for a long time (Pigou et al., 1936; Samuelson, 1937; Morgan, 1945; Georgescu-Roege, 1968). In the economic theory, it is seen that the more money people have, the less value they get from it.

Several variables are related with the attitude toward money like amount of money people have (Tang \& Chiu, 2003), experiences (economic crises, etc.), culture (beliefs, work ethic, etc.), personality (comparison-oriented, ambitious, etc.) and psychological (motivation, etc.) factors. As a result, consumer may be faced with a choice between buying/using high-priced luxury products and having money. At this point, as purchasing high-priced luxury products causes decrease in monetary resources on the one hand and may cause financial resources to be shown to people, on the other hand, answering the question of "which dimension of the love of money affects the choice/avoidance of high-priced luxury brands" will make it easier to understand the subject.

It is possible that the love of money, which consists of; the importance attached to money, seeing money as a motivator, seeing money as a symbol of success, and the importance attached to money (Tang et al., 2002; Tang \& Sutarso, 2013; Tang, 2016), can affect avoiding purchasing luxury brands or products. In short, it is possible that attitudes such as seeing money as one of the most critical assets in life conflict with purchasing and using expensive products or using money as a tool to show success can conflict with buying and using expensive products. However, there is no research on the relationship between the love of money and avoiding purchasing luxury brands in the relevant literature. Based on these explanations, the following research hypotheses are formed:
"H2: The love of money (importance) affects avoiding purchasing high-priced luxury clothing products."
"H3: The love of money (motivation) affects avoiding purchasing high-priced luxury clothing products."
"H4: The love of money (success) affects avoiding purchasing high-priced luxury clothing products."
"H5: The love of money (wealth) affects avoiding purchasing high-priced luxury clothing products."

\section{Field survey}

In this part of the study, research hypotheses are tested with data collected from 372 people in the Kirikkale province of Turkey by convenience sampling method. The data was collected in December 2019 and does not require an ethics committee approval. The variable of avoiding from purchasing was measured in terms of luxury clothing products since luxury clothing is a product category preferred in 
different countries or cultures to meet psychological needs such as self-disclosure and hedonic benefits (Millan et al., 2013).

In this context, to measure the variable of avoiding high-priced luxury clothing brands; Baker \& Churchill (1977), Dodds et al. (1991) and Khan et al.'s (2019) studies are benefited. To measure the love of money Tang et al. (2002), Vitell et al. (2007), Lau et al. (2011), Tang \& Sutarso (2013) and Tang's (2016), studies are benefited. Finally, in order to measure the variable of guilt arising from purchasing luxury clothing products, Holbrook \& Batra (1987), Roseman et al. (1994), Lee-Wingate \& Corfman (2010), Onwezen et al. (2014) and Theotokis \& Manganari's (2014) studies are benefited. A language expert checks translation and meaning accuracy of the translated measurement items to Turkish. In addition to these, questions regarding the demographic characteristics of the participants were also included in the research questionnaire.

\section{Examination of structural validity}

Obtained data is analyzed with AMOS 21 statistical analysis program. At this point, confirmatory factor analyzes were carried out to test the structural validity of research variables first. The fit of the model was evaluated through the goodness of fit values. As a result of the confirmatory factor analysis performed for the research measurement model, the CMIN \& DF value was determined as 2.5, CFI value 0.95 , GFI value 0.88 , NFI value 0.90 and RMSEA value as 0.06 , and it is concluded that the measurement model's goodness of fit values was acceptable. It was determined that the loads from the factor in which the items in the model were included were at a sufficient level, and no item was excluded from the analysis in this regard.

Table 1: Confirmatory Factor Analysis

\begin{tabular}{|c|c|}
\hline & Standard Regression Coefficient \\
\hline \multicolumn{2}{|c|}{ Avoiding purchasing high-priced luxury clothing products (...high-priced luxury clothing products) } \\
\hline I avoid buying & ,858 \\
\hline I don't want to buy & 929 \\
\hline I am more likely to make a decision to buy another brand besides & 824 \\
\hline \multicolumn{2}{|c|}{ Guilt (When I buy high-priced items as it is only prestigious / luxury in clothing products :) } \\
\hline I feel remorse & 803 \\
\hline I feel guilty & 898 \\
\hline I think I did something wrong & 824 \\
\hline I feel like what I'm doing isn't good & 809 \\
\hline I feel uncomfortable & 686 \\
\hline \multicolumn{2}{|c|}{ The Love of Money (Please indicate your level of participation in the following about money :) } \\
\hline \multicolumn{2}{|l|}{ The Love of Money/Importance } \\
\hline Money is attractive & 732 \\
\hline Money is an important factor in the lives of all of us & 818 \\
\hline Money is good & 844 \\
\hline Money is valuable & 849 \\
\hline Money is important & ,782 \\
\hline \multicolumn{2}{|l|}{ The Love of Money/ Success } \\
\hline Money represents my achievement & 667 \\
\hline Money is a symbol of my success & 820 \\
\hline Money reflects my accomplishments & 883 \\
\hline Money is how we compare each other & 804 \\
\hline \multicolumn{2}{|l|}{ The Love of Money/ Motivator } \\
\hline I am motivated to work hard for money & 810 \\
\hline Money reinforces me to work harder & ,848 \\
\hline am highly motivated by money & 831 \\
\hline Money is a motivator & 768 \\
\hline \multicolumn{2}{|l|}{ The Love of Money/ Rich } \\
\hline Having a lot of money (being rich) is good & 721 \\
\hline It would be nice to be rich & 812 \\
\hline I want to be rich & 861 \\
\hline My life will be more enjoyable, if I am rich and have more money & 807 \\
\hline * Turkish version of the items are used in the study & \\
\hline
\end{tabular}


The conformity of the research variables to the assumption of normal distribution was examined with skewness and kurtosis values. If these values are between $-1,5$ and $+1,5$, it can be accepted that the standard distribution assumption is met (Tabachnick and Fidell, 2013). Accordingly, the skewness values are between -0.418 and 0.083 ; kurtosis values were found to vary between $-1,162$ and $-0,854$. Therefore, it was accepted that the data were distributed normally.

Table 2: Analysis of Normal Distribution

\begin{tabular}{|l|l|l|l|l|l|l|}
\hline & $\begin{array}{l}\text { The Love of Money/ } \\
\text { Importance }\end{array}$ & $\begin{array}{l}\text { The Love of Money/ } \\
\text { Motivator }\end{array}$ & $\begin{array}{l}\text { The Love of Money/ } \\
\text { Success }\end{array}$ & $\begin{array}{l}\text { The Love of } \\
\text { Money/ Rich }\end{array}$ & Avoidance & Guilt \\
\hline Skewness &,- 418 &,- 324 &,- 188 &,- 418 &, 344 &, 083 \\
\hline Kurtosis &,- 934 &,- 854 & $-1,099$ &,- 881 & $-1,162$ &,- 957 \\
\hline
\end{tabular}

\section{Testing hypotheses}

Research hypotheses were tested with the structural equation model. As a result of the analysis carried out for the research model, the CMIN \& DF value was determined as 2.49, CFI value as 0.939 , GFI value as 0.878 , NFI value as 0.903 and RMSEA value was 0.063 , and it was concluded that the goodness of fit values of the research model is acceptable. Accordingly, it was determined that the guilt and importance dimension of the love of money positively affect avoidance of purchasing high-priced luxury clothing. On the other hand, it was determined that the success dimension of the love of money negatively affected avoiding. Moreover, there is no effect of motivation and rich dimension of the love of money on avoiding purchasing high-priced luxury clothing brands. Standard regression coefficients of the structural equation model are shown in Table 3:

Table 3: Structural Equation Model

\begin{tabular}{|l|l|l|l|l|}
\hline & & & St. Regression Coefficient & P \\
\hline \multirow{5}{*}{ Avoiding from high priced luxury clothing brands } & $<---$ & Guilt & $\mathbf{5 7 0}$ & $\mathbf{0 , 0 0 0}$ \\
\cline { 2 - 5 } & $<---$ & $\begin{array}{l}\text { The Love of Money/ } \\
\text { Importance }\end{array}$ & $\mathbf{3 4 5}$ & $\mathbf{0 , 0 0 3}$ \\
\cline { 2 - 6 } & $<---$ & $\begin{array}{l}\text { The Love of Money/ } \\
\text { Success }\end{array}$ & $\mathbf{-}, \mathbf{4 4 7}$ & $\mathbf{0 , 0 0 5}$ \\
\cline { 2 - 6 } & $<---$ & $\begin{array}{l}\text { The Love of Money/ } \\
\text { Motivator }\end{array}$ &,- 061 & 0,614 \\
\cline { 2 - 6 } & $<---$ & $\begin{array}{l}\text { The Love of Money/ } \\
\text { Rich }\end{array}$ &, 250 & 0,117 \\
\hline
\end{tabular}

As can be seen in Table 3., as a result of the finding that the guilt about purchasing high-priced luxury clothing products positively affects avoiding purchasing these products, "H1: The feeling of guilt originating from luxury consumption affects the avoidance of purchasing high-priced luxury products" hypothesis has been supported. Besides, it was determined that the essential factor of the love of money, which expresses the importance given to money, affects avoidance positively and significantly and the hypothesis of "H2: The Love of money (importance) affects avoiding purchasing high-priced luxury clothing products" is supported. Third, it was found that the motivation factor of the love of money does not affect avoidance of purchasing luxury clothing, and hence the hypothesis that "H3: The Love of money (motivation) affects avoiding purchasing high-priced luxury clothing products" was not supported. Fourthly, the success dimension of the love of money variable has been found to have an inverse and significant effect on avoiding purchasing high-priced luxury clothing products. The hypothesis that "H4: The love of money (success) affects avoiding purchasing high-priced luxury clothing products" is supported. Finally, it was determined that the rich dimension of the love of money positively affects avoidance of luxury brands, but this effect was not significant, and the hypothesis "H5: The love of money (wealth) affects avoiding purchasing high-priced luxury clothing products" was not supported. 


\section{Discussion and conclusion}

The study's finding that emotion of guilt affects avoiding purchasing high-priced luxury clothing products; is similar to the research results showing that quilt affects hedonistic consumption (Okada, 2005; Chun et al., 2007) and avoiding high-priced purchasing products (Nowlis \& Simonson, 1996). This result is consistent with research results showing that consumers can prefer low-priced products (De Lenne \& Vandenbosch, 2017) to reduce guilt. This result is similar to Ki et al.'s (2017) research results showing that the guilt emotion decreases the repeat purchasing behaviour of the consumer.

The research findings show that depending on importance dimension of the love of money, the consumer may prefer money instead of purchasing luxury products. In other words, it is understood that the increased importance is given to money positively affects avoiding luxury clothing brands. On the other hand, it is thought that the negative effect of the success dimension of the love of money to avoid luxury consumption, which expresses the use of money as a success symbol, is due to the display or social nature of this dimension of the love of money. Because using money itself as a symbol or indicator of success; is more about the purchase and use of products. However, using money itself as an indicator of success, although it is possible especially for close acquaintances, can be expected to be more limited due to reasons such as socially damaging evaluation anxiety.

The reason why the rich and motivation dimensions of the love of money, which express the importance given to motivation and wealth, do not affect the avoidance of luxury clothing purchasing, can be related to that these dimensions are about using the money as a tool to increase motivation in life or having some to products, instead of giving importance to possessing or holding money.

The research results show that the guilt and the love of money (especially importance and success dimensions) should be crucial for businesses that market high-priced luxury clothing products. Accordingly, these results would be beneficial for companies, and several suggestions can be made. Since marketing communications that reduce guilt can be expected to reduce avoidance of purchasing luxury clothing products, these firms had better be aware of the potential of the guilt emotion and struggle to manage them. Also, it is understood that luxury clothing product marketers can affect the purchasing intentions of consumers by affecting attitudes towards the money of consumers. Moreover, variables of the love of money and guilt emotion can be considered as market segmentation criteria.

The study results would be expected helpful for marketing/consumer scientists, too, especially for studies that examine preferences and intentions toward luxury clothing products. Moreover, since the love of money and guilt can be effective in studies analyzing consumer intention and behaviours toward other luxury products like cosmetics, jewellery, or even automobile, it is recommended that researchers consider them for more possible meaningful research models. In this way, our scientific knowledge about this neglected aspect of consumer behaviour would be increased.

As every research has constraints, this study also has some constraints. First, due to the descriptive nature of the research, it does not show cause and effect relationships among research variables. Furthermore, it is assumed that participants give honest answers to survey items. Besides, the fact that the research is conducted in a narrow geographical area is another constraint that prevents the generalization of the findings. However, it is hoped that the research will be useful in terms of drawing attention to a dimension of consumer intention that has not been studied widely and contributing to filling the mentioned gap in the literature.

\section{Peer-review:}

Externally peer-reviewed

\section{Conflict of interests:}

The author has no conflict of interest to declare.

\section{Grant Support:}

The author declared that this study has received no financial support 


\section{Acknowledgement:}

The author sincerely thanks to TUJOM officials for scientific effort and interest.

\section{References}

Ahuvia, A. (1992). For the love of money: Materialism and product love. Association for Consumer Research, Special Volumes, 188-198.

Arli, D., Leo, C., \& Tjiptono, F. (2016). Investigating the impact of guilt and shame proneness on consumer ethics: A cross national study. International Journal of Consumer Studies, 40(1), 2-13.

Bakar, A., Lee, R., \& Hazarina H. N. (2013). Parsing religiosity, guilt and materialism on consumer ethics. Journal of Islamic Marketing, 4(3), 232-244.

Baker, M.J. \& Churchill, G.A. (1977). The impact of physically attractive models on advertising evaluations. Journal of Marketing Research, 14(4), 538-555.

Basil, D.Z., Ridgway, N.M. \& Basil, M. (2006) Guilt appeal: the mediating effect of responsibility. Psychology and Marketing, 23(12), 1035-1054.

Bonsu, S., \& Main, K. (2006). Consumer guilt: Preliminary construct assessment and scale development. ACR Asia-Pacific Advances.

Boujbel, L., \& d'Astous, A. (2015). Exploring the feelings and thoughts that accompany the experience of consumption desires. Psychology \& Marketing, 32(2), 219-231.

Burnett, M. S., \& Lunsford, D. A. (1994). Conceptualizing guilt in the consumer decision-making process. Journal of Consumer Marketing, 11(3), 33-43.

Chen, J., Tang, T. L. P., \& Tang, N. (2014). Temptation, monetary intelligence (love of money), and environmental context on unethical intentions and cheating. Journal of Business Ethics, 123(2), 197219.

Chun, H., Patrick, V. M., \& MacInnis, D. J. (2007). Making prudent vs. impulsive choices: the role of anticipated shame and guilt on consumer self-control. ACR North American Advances.

Chun-Tuan C. (2011) Guilt appeals in cause-related marketing, International Journal of Advertising, 30(4), 587-616.

Cruz, B. D. P. A., Pires Jr, R. J. M., \& Ross, S. D. (2013). Gender difference in the perception of guilt in consumer boycott. Revista Brasileira de Gestão de Negócios, 15(49), 504-523.

Dahl D. W., \& Honea H. (2005) Three Rs of interpersonal consumer guilt: Relationship, Reciprocity, Reparation. Journal of Consumer Psychology, 15(4), 307-315.

Dahl, D. W., Honea, H., \& Manchanda, R. V. (2003). The nature of self-reported guilt in consumption contexts. Marketing Letters, 14(3), 159-171.

Daniel J. O. (2000). Guilt and social influence. Annals of the International Communication Association, 23(1), 67-101.

De Lenne, O., \& Vandenbosch, L. (2017). Media and sustainable apparel buying intention. Journal of Fashion Marketing and Management, 21(4), 483-498.

Dodds W.B., Monroe K.B., Grewal D. (1991). Effects of price, brand, and store information onbuyers' product evaluations. Journal of Marketing Research, 28(3), 307-19.

Styvén, M., \& Mariani, M. M. (2020). Understanding the intention to buy second-hand clothing on sharing economy platforms: The influence of sustainability, distance from the consumption system, and economic motivations. Psychology E Marketing, 37(5), 724-739. 
Elias, R. Z., \& Farag, M. (2010). The relationship between accounting students' love of money and their ethical perception. Managerial Auditing Journal, 25(3), 269-281.

Flurry, L. A., \& Swimberghe, K. (2016). Consumer ethics of adolescents. Journal of Marketing Theory and Practice, 24(1), 91-108.

Freudenreich, B., \& Schaltegger, S. (2020). Developing sufficiency-oriented offerings for clothing users: Business approaches to support consumption reduction. Journal of Cleaner Production, 247, 119589, 110 .

Georgescu-Roegen, N. (1968). Revisiting Marshall's constancy of marginal utility of money. Southern Economic Journal, 176-181.

Gram, M., Hohnen, P., \& Pedersen, H. D. (2017). 'You can't use this, and you mustn't do that': A qualitative study of non-consumption practices among Danish pregnant women and new mothers. Journal of Consumer Culture, 17(2), 433-451.

Hagtvedt, H. \& Patrick, V.M. (2015). Gilt and guilt: should luxury and charity partner at the point of sale?. Journal of Retailing, 92(1), 56-64.

Hamilton, K. (2009). Consumer decision making in low-income families: The case of conflict avoidance. Journal of Consumer Behaviour: An International Research Review, 8(5), 252-267.

Hanks, L., \& Mattila, A. S. (2014). The impact of gender and prepurchase mood on consumer guilt after a travel purchase. Journal of Travel Research, 53(5), 625-637.

Hibbert, S., Smith, A., Davies, A. \& Ireland, F. (2007) Guilt appeals: persuasion knowledge and charitable giving. Psychology \& Marketing, 24(8), 723-742.

Holbrook, M. B., \& Batra, R. (1987). Assessing the role of emotions as mediators of consumer responses to advertising. The Journal of Consumer Research, 14(3), 404-420.

Huhmann, B. A., \& Brotherton, T. P. (1997). A content analysis of guilt appeals in popular magazine advertisements. Journal of Advertising, 26(2), 35-45.

Izard, C.E. (1977). Human emotions. New York: Plenum.

Joanes, T. (2019). Personal norms in a globalized world: Norm-activation processes and reduced clothing consumption. Journal of Cleaner Production, 212, 941-949.

Khan, M. A., Ashraf, R., \& Malik, A. (2019). Do identity-based perceptions lead to brand avoidance? A cross-national investigation. Asia Pacific Journal of Marketing and Logistics, 31(4), 1095-1117.

Ki, C., Lee, K., \& Kim, Y. K. (2017). Pleasure and guilt: how do they interplay in luxury consumption?. European Journal of Marketing, 51(4), 722-747.

Kozinets, R. V., Handelman, J. M. \& Lee, M.S.W. (2010). Don't read this; or, who cares what the hell anticonsumption is, anyways?. Consumption Markets $\mathcal{E}$ Culture, 13 (3), 225-233.

Krugler, K., \& Jones, W. H. (1992). On conceptualizing and assessing guilt. Journal of Personality and Social Psychology, 62(2), 318-327.

Lascu, D. (1991). Consumer guilt: Examining the potential of a new marketing construct. Advances in Consumer Research, 18, 290-293.

Lau, T. C., Choe, K. L., \& Tan, L. P. (2011). Consumers' ethical beliefs: ascertaining the roles of money and religiosity. International Conference on Sociality and Economics Development, 10, 162-166.

Lee, M. S., Motion, J., \& Conroy, D. (2009). Anti-consumption and brand avoidance. Journal of Business Research, 62(2), 169-180.

Lee, M. S.W., Hélène, C., Roux, D. \& Cova, B. (2011). Anti-consumption and consumer resistance: Concepts, concerns, conflicts, and convergence. European Journal of Marketing, 45 (11/12): 1680-1687.

Lee-Wingate, S. N. (2006). Alleviating mommy's guilt: Emotional expression and guilt appeals in advertising. Association for Consumer Research,33, 262. 
Lee-Wingate, S. N., \& Corfman, K. P. (2010). A little something for me and maybe for you, too: promotions that relieve guilt. Marketing Letters, 21(4), 385-395.

Lin, Y. T., \& Xia, K. N. (2009). The relationship between consumer guilt and product categories. ACR Asia-Pacific Advances, 332-333.

Marcos, J. (2020). Mixed messages: Examining external barriers to university student ethical clothing consumption. DePaul Discoveries, 9(1), 6.

McGraw, K. M. (1987). Guilt following transgression: An attribution of responsibility approach. Journal of Personality and Social Psychology, 53(2), 247.

McNeill, L., \& Moore, R. (2015). Sustainable fashion consumption and the fast fashion conundrum: fashionable consumers and attitudes to sustainability in clothing choice. International Journal of Consumer Studies, 39(3), 212-222.

Miao, L. (2011). Guilty pleasure or pleasurable guilt? Affective experience of impulse buying in hedonicdriven consumption. Journal of Hospitality and Tourism Research, 35 (1), 79-101.

Millan, E., De Pelsmacker, P., \& Wright, L. T. (2013). Clothing consumption in two recent EU Member States: A cross-cultural study. Journal of Business Research, 66(8), 975-982.

Morgan, J. N. (1945). Can we measure the marginal utility of money?. Econometrica: Journal of the Econometric Society, 129-152.

Nowlis, S. M., \& Simonson, I. (1996). The effect of new product features on brand choice. Journal of Marketing Research, 33, 36-46.

Okada, E. M. (2005). Justification effects on consumer choice of hedonic and utilitarian goods. Journal of Marketing Research, 42, 43-53.

Oliver, R. L. (1993). Cognitive, affective, and attribute bases of the satisfaction response. Journal of Consumer Research, 20 (3), 418-30.

Onwezen, M. C., Bartels, J., \& Antonides, G. (2014). Environmentally friendly consumer choices: Cultural differences in the self regulatory function of anticipated pride and guilt. Journal of Environmental Psychology, 40, 239-248.

Peloza J., White K., \& Shang J. (2013). Good and guilt-free: The role of self-accountability in influencing preferences for products with ethical attributes. Journal of Marketing, 77(1), 104-119.

Pigou, A. C., Friedman, M., \& Georgescu-Roegen, N. (1936). Marginal utility of money and elasticities of demand. The Quarterly Journal of Economics, 50(3), 532-539.

Rawlings EI. (1970). Reactive guilt and anticipatory guilt in altruistic behaviour. In: Macaulay JR, Berkowitz L, (Eds.), Altruism and helping behaviour. New York: Academic Press.

Riad, S. (2011). Towards inconspicuous consumption and quest; luxury and its pedlars in the current world climate. Journal of Revenue \& Pricing Management, 10(1), 99-102.

Roseman, I. J., C. Wiest \& T. S. Swartz: (1994). Phenomenology, Behaviours, and Goals Differentiate Discrete Emotions. Journal of Personality and Social Psychology, 67(2), 206-221.

Samuelson, P. A. (1937). A note on measurement of utility. The Review of Economic Studies, 4(2), 155-161.

Soscia, I., Busacca, B., \& Pitrelli, E. (2008). Guilt decreasing marketing communication: An unexplored appeal. Association for Consumer Research, 8, European Advances, 107-108.

Steenhaut, S., \& Van Kenhove, P. (2006). The mediating role of anticipated guilt in consumers' ethical decision making. Journal of Business Ethics, 69(3), 269-288.

Sukhdial, A., \& Boush, D. M. (2004). Eating guilt: Measurement and relevance to consumer behaviour. Advances in Consumer Research, 31, 575-576.

Tabachnick, B.G. \& L.S. Fidell (2013), Using multivariate statistics. Boston: Pearson.

Tang, T. L. P. (2016). Theory of monetary intelligence: Money attitudes-religious values, making money, making ethical decisions, and making the grade. Journal of Business Ethics, 133(3), 583-603. 
Tang, T. L. P., Chiu, R.K., et al. (2002). Is the love of money the root of all evil? Or different strokes for different folks: Lessons in 12 countries. International Conference on Business Ethics in the Knowledge Economy, Hong Kong, China.

Tang, T. L. P., \& Chen, Y. J. (2008). Intelligence vs. wisdom: The love of money, Machiavellianism, and unethical behaviour across college major and gender. Journal of Business Ethics, 82(1), 1-26.

Tang, T. L. P., \& Chiu, R. K. (2003). Income, money ethic, pay satisfaction, commitment, and unethical behaviour: Is the love of money the root of evil for Hong Kong employees?. Journal of Business Ethics, 46(1), 13-30.

Tang, T. L. P., \& Sutarso, T. (2013). Falling or not falling into temptation? Multiple faces of temptation, monetary intelligence, and unethical intentions across gender. Journal of Business Ethics, 116(3), 529552.

Tang, T. L. (2007). Income and quality of life: Does the love of money make a difference?. Journal of Business Ethics, 72, 375-93.

Tang, T. L. \& Liu, H. (2012). Love of money and unethical behaviour intention: Does an authentic supervisor's personal integrity and character (ASPIRE) make a difference?. Journal of Business Ethics, 107 (3), 295-312.

Theotokis A., \& Manganari E. (2014).The impact of choice architecture on sustainable consumer behaviour: The role of guilt. Journal of Business Ethics, 19(2), 169-194.

Vitell, S. J., Paolillo, J. G., \& Singh, J. J. (2006). The role of money and religiosity in determining consumers' ethical beliefs. Journal of Business Ethics, 64(2), 117-124.

Vitell, S. J., Singh, J. J., \& Paolillo, J. G. (2007). Consumers' ethical beliefs: The roles of money, religiosity and attitude toward business. Journal of Business Ethics. 73(4), 369-379.

Watson, L. \& Spence, M. T. (2007). Causes and consequences of emotions on consumer behaviour: A review and integrative cognitive appraisal theory. European Journal of Marketing, 41(5/6), 487-511.

Xu, J, Schwarz, N. (2009). Do we really need a reason to indulge?. Journal of Marketing Research, 46(1), 25-36. 